\title{
A Cultural History of Heredity
}

\author{
Jenny Marie \\ Max Planck Institute for the History of Science
}

There are two aspects to the Cultural History of Heredity project jointly run by Staffan Müller-Wille and Hans-Jörg Rheinberger. The first is a series of workshops, which are held biennially on the subject and the second is a small research group. This report looks at both aspects of the project and the resources that it provides for studying the history of heredity.

What, though, is a cultural history of heredity? The clue is perhaps in the word 'heredity'. The project does not aim to study the science of heredity, which in the twentieth century was genetics. Instead, we study the history of ideas about inheritance, whomever they were held by. Understanding heredity this way makes it almost necessary for the history to be cultural. However, the project's participants are particularly interested in the crossing of cultural domains by this hereditary knowledge (e.g. from science to popular culture and vice versa) and more specifically, in the way that practices can act as vectors by which these ideas cross cultural domains.

There have now been three workshops run by the project and another two are planned for the foreseeable future. The first workshop concluded that there was no general concept of heredity during the seventeenth and early eighteenth centuries. However, hereditary ideas existed in some specific domains, such as in the practices of plant hybridisation, explanations of disease and the organisation of colonial societies on racial characters. Approaches to the question of generation were highly diverse, and not just guided by the preformation / epigenesis debates. A report of the conference can be obtained from http://www.mpiwg-berlin.mpg.de/HEREDITY/ REPORT1.html and some of the papers given at the conference are available from http://www. mpiwg-berlin.mpg.de/Preprints/P222.pdf.

The second workshop focused on the period from Kant's publication of Von den verschiedenen Rassen der Menschen in 1775 to Darwin's publication of The Variation of Animals and Plants under Domestication in 1868. It concluded that by the end of the period heredity was a central concept of the life sciences and, as it became so, certain shifts occurred in the understanding of heredity that existed in medicine, breeding, natural history and anthropology. Heredity became the phenomenon of parental and filial relationships and it became mosaic rather than a phenomenon of the general morphology of species. A report of this conference is available from http://www.mpiwgberlin.mpg.de/HEREDITY/REPORT2.html and some of the papers presented are available from
http://www.mpiwg-berlin.mpg.de/Preprints/P247. pdf. Results of the first two workshops have been brought together by Staffan Müller-Wille and HansJörg Rheinberger at http://www.mpiwg-berlin.mpg. de/Preprints/P276.PDF.

The third workshop focused on the period from Galton's Hereditary Genius of 1869 to Wilhelm Johannsen's "Experimente über die Vererbung des Samengewichtes bei Phaseolus-Bohne" of 1903. The workshop investigated the different contexts in which heredity was investigated during this period. These included statistics, evolutionary theory, physiological theories, sociology, psychology, genealogy and anthropology. Abstracts of the talks are available at http://www.mpiwg-berlin.mpg. de/HEREDITY/Abstract Reader 2005.pdf.

The next workshop in the series will focus on how molecular biology and conceptions regarding it came about. In particular it will focus on how molecular biology brought together ideas that had existed in a wide variety of domains during the first half of the twentieth century. This workshop is currently planned to be held at Exeter University circa January 2007.

The final workshop in the series will focus on how the advent of gene technologies has impacted many areas of our daily lives, from the food we buy to the evidence offered in law courts. It will also consider how genetics could develop when genome sequencing becomes routine.

The workshops are just one part of the 'A Cultural History of Heredity' project. The other half is a working group of researchers, mainly based at the Max Planck Institute for the History of Science. This working group currently consists of five members, two of whom are postdoctoral fellows. The Max Planck Institute funds one of these fellowships and the Liechtenstein Government funds the other through the institute. The project thus has a limited supply of funding available to support postdoctoral fellows. Below I describe the current research being undertaken by this group so that potential applicants for such positions can better understand the type of interests that the project encourages.

Hans-Jörg Rheinberger is currently researching the material characteristics of different experimental systems that were used for hereditary research in Germany at the end of the nineteenth century and during the first half of the twentieth century. These systems were created by various scholars, who did so by drawing on their different disciplinary backgrounds. Hans-Jörg is focusing on six main experimental systems. The first area of focus is the pea and corn hybridisation work of 
Carl Correns, which led him to rediscover the Mendelian laws. However, the study extends beyond this to Correns's work on variegation and his views on extra-chromosomal inheritance. The second focus is Alfred Kühn's group's work on the flour moth, which brought together considerations of transmission genetics and developmental physiology. The third is the Kaiser-Wilhelm Institute's work on the Tobacco Mosaic Virus, which combined biological, chemical and physical approaches to studying the genetic material. The fourth is Max Hartmann's protozoology work on fertilisation, reproduction and sexuality and the relation it had to genetics. Hans-Jörg also plans to research Richard Goldschmidt's research on sex determination and Fritz von Wettstein's research on cytoplasmic inheritance in mosses.

Staffan Müller-Wille, who is now based at Exeter University, has researched a variety of subjects for the project. These have included Linnaeus's ideas about heredity and how his classificatory system provided an important context for Mendel's hereditary work. Currently, Staffan is researching developments in anthropology and their relations to genetics at the start of the twentieth century. He is trying to understand the genealogy by which both questions of heredity in genetics and kinship systems in social anthropology became structuralist at the end of the nineteenth century and the start of the twentieth. He also seeks to understand why this occurred when this seemed to be incompatible with concepts such as evolution and adaptation and the idea of wholes, such as races, cultures and people.

Bernd Gausemeier also focuses on changes that occurred to ideas about heredity at the turn of the twentieth century. His interest is in how genealogy changed from being a practice that represented the social status of families into something that focused on the transmission of deviances in Germany. Bernd argues that genealogy structured concepts of human heredity and, since it provided a historical dimension, it also added questions of higher significance. Bernd therefore argues that this change in genealogy was important to the rise of eugenics.

My own work looks at the relationship between geneticists, animal breeders and gardeners in the first forty years of the twentieth century. I argue that animal breeders served as a link between geneticists, reproductive physiologists and husbandry men. This, among other things, encouraged genetics to remain a broad discipline in Britain. I also investigate the context that horticulture provided for genetics. I have noted that the International Genetical Conference series was originally a horticultural conference series, and many of the early genetic organisms were garden plants or insects that harmed them.
Christina Brandt is conducting a comparative study of the history of cloning in the latter half of the twentieth century. She investigates changes in German developmental biology and how this provided a background for the development of cloning techniques. She also looks at changes concerning scientific concepts of cloning. She explores how the term has been applied to plants that were propagated vegetatively, to cell cultures, gene cloning and finally to organisms. The final aspect of her work is the consideration of how clones have been represented in novels and scientific fiction, and how this has impacted public debates on cloning.

The project is thus fairly wide-ranging, as any project looking at the connections between genetics and other cultural domains would need to be. It provides the opportunity for scholars to discuss cultural histories of heredity at its conferences, and Internet access to the outcomes of these discussions. It also provides some support for postdoctoral and research scholars who work on cultural aspects of hereditary history. 